\title{
The 1967 Referendum
}

\author{
Lucinda Kranjc
}

University of Technology Sydney, Faculty of Arts and Social Sciences, PO Box 123, Ultimo NSW 2017, Australia. lucinda.kranjc@student.uts.edu.au

\section{DOI: $\underline{\text { https://doi.org/10.5130/nesais.v4i1.1526 }}$}

The 1967 Referendum symbolised the political and legal emancipation of the Aboriginal and Torres Strait Islander people. However, despite the high hopes the referendum set out to achieve, the equivocation of the 'yes' vote over constitutional reform led to no real or clear-cut changes at all.

Prior to the 1967 Referendum, government policies such as 'assimilation' were popular, which Rowse (2000) states was viewed as a more 'positive' program by the government. However, this policy received a lot of criticism as its objective was to have Aboriginal people adopt the same way of life as the colonial Australian community (Rowse 2000, p. 17). Rowse points out that Stanner, among other critics, derived problems from this policy: it denied difference, favouring 'sameness' and ultimately leading to the abandonment of Aboriginal culture, prompting mass retaliation from the Aboriginal people (Rowse 2000, p. 25). Therefore, the Aboriginal people were in dire need of political reform and activism, which was the goal of changing Section 51 Clause xxvi and Section 127 of the Constitution. Amending these clauses would enable Indigenous people to be counted in the census, and to empower the Federal Government to make laws that would economically benefit the Aboriginal people (Bandler 1989, p. 82).

Bandler (1989) argued that the 1967 Referendum would profoundly impact the lives of Indigenous people through the abolition of racially discriminatory legislation, enhanced federal intervention on policies and funding alongside the state as well as constitutional recognition of Aboriginal customs (Bandler 1989, p. 110). Attwood (1997) offered an opposing perspective, arguing that after the overwhelming success of the referendum for constitutional reform, nothing had changed in regard to the advancement and bettering of Aboriginal affairs (Attwood 1997, p. 60). The government had planned to merely maintain their current situation which had ironically placed the power back into the grip of the states, as the Commonwealth did not want to undertake any grand initiatives in fear of 'overstating' the reality of the Aboriginal problem. Thus, he argues it had "eased the guilty conscience of white Australians" but failed to implement any constitutional change to advance Aboriginal affairs. Thus, the referendum acted as a 'symbolic gesture' for federal activism only (Attwood 1997, p. 61).

Therefore, we can draw from the political activism of the 1967 Referendum outlined by Attwood and Bandler that clear-cut and non-ambiguous initiatives should coincide with constitutional change in order for real, positive change on Aboriginal affairs to occur. 


\section{References}

Attwood, B. 1997, The 1967 Referendum, or when Aborigines didn't get the vote, Aboriginal Studies Press, Canberra.

Bandler, F. 1989, 'The Referendum', Turning the tide: a personal history of the Federal Council for the Advancement of Aborigines and Torres Strait Islanders, Aboriginal Studies Press, Canberra, pp. 79-110.

Rowse, T. 2000, 'The modest mandate of 1967', Obliged to be difficult: Nugget Coombs' Legacy in Indigenous Affairs, Cambridge University press, Cambridge, pp. 17-33.

https://doi.org/10.1017/CBO9780511552199.002

(c) (i) (C) 2018 by the author(s). This article is distributed under the terms and conditions of the Creative Commons Attribution license (http://creativecommons.org/licenses/by-nd/4.0/). 